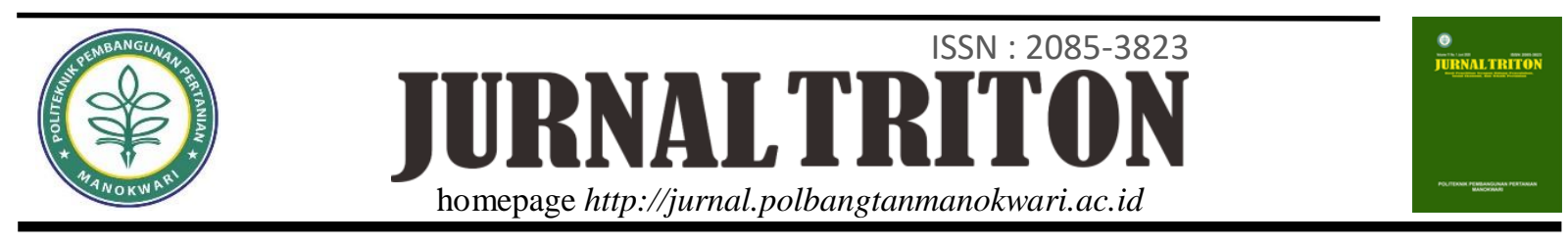

\title{
Perbandingan Metode Isolasi pada Deteksi Kulit Sapi, Kerbau, Kambing, dan Babi sebagai Bahan Baku Rambak Kulit
}

\author{
Dyah Triasih $^{1 *}$, Rulli Riana Dewi ${ }^{2}$, Yuny Erwanto ${ }^{3}$, Nanung Agus Fitrianto ${ }^{4}$ \\ ${ }^{1}$ Program Studi Pengolahan Hasil Ternak, Politeknik Negeri Banyuwangi \\ 2,3,4 Departemen Teknologi Hasil Ternak, Fakultas Peternakan, Universitas Gadjah Mada
}

\begin{tabular}{l}
\multicolumn{1}{c}{ ARTIKEL INFO } \\
\hline Sejarah artikel \\
Diterima $18 / 05 / 2020$ \\
Diterima dalam bentuk revisi 25/06/2020 \\
Diterima dan disetujui 26/06/2020 \\
Tersedia online 30/06/2020 \\
\hline Kata kunci : \\
DNA \\
Metode wasko \\
Metode sambrook \\
Kulit \\
PCR-RFLP \\
\hline
\end{tabular}

\begin{abstract}
ABSTRAK
Kulit adalah hasil samping dari pemotongan ternak yang seiring waktu semakin meningkat permintaan konsumen bersamaan dengan meningkatnya pertumbuhan penduduk. Hal ini yang mendorong produsen berinovasi menciptakan produk baru. Salah satu inovasi produk yaitu pada rambak kulit. Tujuan dari penelitian ini untuk mengidentifikasi bahan dasar yang digunakan pada rambak kulit. Salah satunya dengan analisis genetik melalui penanda molekuler. Keberhasilan teknik molekuler ditentukan oleh tertangkapnya DNA genom dari sampel. Tahapan utama analisis genetik adalah isolasi DNA. Metode Sambrook dan metode Wasko yang telah dimodifikasi digunakan dalam penelitian ini. Sampel yang digunakan berupa kulit sapi, kerbau, kambing, dan babi dalam keadaan segar yang telah diawetkan dalam freezer dengan suhu $-20^{\circ} \mathrm{C}$. konsentrasi dan kemurnian DNA diukur dengan spektrofotometer pada $\lambda 260$ dan 2280 . Amplifikasi gen cytochrome b menggunakan primer universal. Elektroforesis menggunakan agarose sebesar $0,8 \%$ untuk isoalsi DNA dan 1,5\% untuk amplifikasi PCR selama 30 menit dengan tegangan 100 volt. Berdasarkan hasil penelitian menunjukkan bahwa metode Sambrook yang telah dimodifikasi memberikan hasil yang baik, pita DNA yang dihasilnya terlihat secara jelas dibandingkan dengan menggunakan metode Wasko yang telah dimodifikasi. Konsentrasi dan kemurnian DNA metode Sambrook lebih baik dibandingkan dengan metode Wasko. Amplifikasi PCR gen cytochrome $b$ menghasilkan produk PCR sebesar 359 bp pada kulit sapi, kerbau, kambing, dan babi.
\end{abstract}

(C) 2020 Politeknik Pembangunan Pertanian Manokwari 


\section{ABSTRACT}

Skin is the the side products from cattle slaughtering. Along with the growth of the population, the needs of the food products increased. This encourages the manufacturer to innovate, create new products according to the market, but not rarely the manufacturer mix the raw materials used. One of the product innovations is skin rambak. The purpose of this research is to identify the basic materials used in skin rambak. One only with genetic analysis through molecular markers. Result of the molecular technique is determined by the DNA is the genome from the sample. The main stages of genetic analysis is the isolation of the DNA. Sambrook method and the modified Wasko method used in this research. The sample used in the form of cow skin, buffalo, goats, and pigs in the fresh state that has been

\section{PENDAHULUAN}

Keamanan pangan merupakan salah satu faktor penting yang harus menjadi pertimbangan dalam menentukan makanan yang dapat dikonsumsi, tidak hanya berkaitan dengan aspek kesehatan namun kehalalan dalam suatu makanan yang harus menjadi perhatian. Hal ini karena di Indonesia penduduknya mayoritas beragama muslim. Mengkonsumsi produk makanan halal agama islam untuk meningkatkan kualitas hidup yang dijamin oleh Undang - Undang Dasar 1945, khususnya Undang - Undang Perlindungan Konsumen Nomor 8 Tahun 1999 serta mengkonsumsi yang halal itu merupakan kewajiban bagi setiap muslim.

Pengolahan makanan di era modern sudah sangat kompleks. Produsen menggunakan berbagai teknologi untuk memproduksi suatu produk makanan. Namun dalam memproduksi makanan banyak dimasukkan bahan tambahan termasuk bahan pewarna. Kurang akses komunikasi antara produsen dengan konsumen mulai dari pengadaan bahan baku dan bahan tambahan, preserved in the freezer with the temperature $-20^{\circ} \mathrm{C}$. The concentration and purity of DNA were measured with spectrophotometer on $\lambda 260$ and $\lambda 280$. Amplification of genes cytochrome $b$ using universal primary. Agarose 0.8 percent of isolate DNA and 1.5 percent for amplification PCR for 30 minutes with the voltage 100 volts. Based on the results of the study showed that the modified Sambrook method provided good results, the result DNA band had been compared using a modified Wasko method. The concentration and purity of DNA Sambrook method were better than the Wasko method. Amplification $P C R$ genes cytochrome $b$ produces $P C R$ products of 359 bp on the skin of a cow, buffalo, goats, and pigs.

proses pengolahan, pengemasan, distribusi pengangkutan, dan penjualan akibatnya sulit untuk mengetahui kehalalan suatu produk makanan.

Metode analisis yang digunakan dalam mendeteksi bahan dasar yang digunakan dalam suatu produk pangan adalah dengan metode analisis berbasis protein maupun DNA. Metode berbasis protein meliputi elektroforesis SDSPAGE sedangkan yang berbasis DNA meliputi PCR amplifikasi DNA mitokondria, analisis PCR-RFLP, dan PCR Sequencing. Kendala yang muncul dalam metode yang berbasis DNA adalah mudah tidaknya isolasi DNA. DNA berkualitas tinggi yang didapat dalam suatu ekstraksi merupakan suatu kaidah dasar yang harus dipenuhi dalam studi molekuler.

Isolasi DNA merupakan tahap awal dalam menentukan tingkat keberhasilan untuk tahap selanjutnya. Belum adanya penelitian tentang isolasi DNA pada kulit hewan maka dari itu diperlukan penelitian tentang isolasi DNA pada kulit sebagai bahan dasar dalam pembuatan rambak kulit. Metode umum yang digunakan untuk isolasi DNA yang mengalami 
modifikasi sehingga dapat digunakan untuk mengisolasi kulit hewan. Oleh karena itu diperlukan suatu metode untuk menguji tingkat efektifitasnya dalam mengisolasi DNA untuk mendapatkan hasil yang terbaik secara kuantitas dan kualitas DNA yang dihasilkan serta efisiensi waktu dalam pengerjaannya dalam mengisolasi DNA kulit hewan untuk mendeteksi bahan dasar yang digunakan dalam rambak kulit. Tujuan dari penelitian ini adalah untuk mencari metode isolasi DNA yang terbaik untuk mendeteksi bahan dasar pada produk rambak. Hasil penelitian ini diharapkan dapat memberikan informasi kepada masyarakat sebagai identifikasi bahan dasar yang digunakan dalam produk rambak kulit sehingga dapat digunakan dalam pencegahan terhadap pemalsuan produk makanan.

\section{METODE}

Bahan yang digunakan sebagai sampel dalam penelitian ini adalah kulit sapi, kulit kerbau, kulit kambing dan kulit babi dalam kualitas kulit segar yang diawetkan. Bahan lainnya seperti buffer TEN/STE (10 mM Tris HCl, 1 mM EDTA, 0,1 M NaCl) (Merc), larutan Phosphat Buffer Saline (PBS) (Merc), larutan Sodium dodecyl sulfate (SDS) 10\% (Merc), larutan proteinase $\mathrm{K}$ (Thermo Scientific), larutan $\mathrm{NaCl} 5 \mathrm{M}$ (Merc), Larutan Phenol (Merc), larutan Chloroform Isoamyl Alcohol (CIAA) (Merc), larutan Chloroform (Merc), Isoamil alkohol (Merc), larutan Ethanol 100\% (Ethanol absolut), RNAase (Invitrogen) larutan Ethanol 70\% (Merc), Larutan Tris EDTA (TE), Maxima Hot Start Green PCR Master Mix (Thermo Scientific), aquabidest, buffer Tris
Boric EDTA (TBE) 1X, Ethidium bromide, agarose (Thermo Scientific), DNA ladder (Thermo Scientific), dan Loading dye (Thermo Scientific). Alat yang digunakan dalam penelitian ini adalah mortar, Refrigerated Microcentrifuge $(>10.000 \mathrm{x} \mathrm{g})$, tabung ependorf $0,2 \mathrm{ml}$, tabung ependorf $0,5 \mathrm{ml}$ atau $1,5 \mathrm{ml}$, kotak penyimpanan sampel, rak tabung eppendorf, waterbath, vortex mixer, pipetor atau pipetmen, tip pipet (warna putih, biru dan kuning), sarung tangan (hand glove), masker, autoclave, nanodrop spektrofotometer, mesin Thermal cycler, horizontal agarose gel electrophoresis apparatus (MUPID), Wellforming combs (sisir pembentuk sumur), power supply, microwafe atau hotplate, UV transilluminator, dan camera digital. Kulit segar sapi, kerbau, kambing, dan babi dibeli dari RPH Giwangan di wilayah Yogyakarta. Kulit dipotong kecil-kecil secara terpisah untuk menghindari kontaminasi, setelah itu dilakukan pengepakan kulit kemudian disimpan pada suhu $-20^{\circ} \mathrm{C}$ sampai digunakan untuk penelitian dapat dilihat pada tabel 1 .

Tabel 1. Perbandingan sampel kulit sapi, kerbau, kambing dan kulit babi

\begin{tabular}{lll}
\hline \hline No. & Sampel & $\begin{array}{l}\text { Perbandingan } \\
\text { Presentase Kulit }\end{array}$ \\
\hline 1. & Kulit Sapi & $100 \%$ \\
2. & Kulit Kerbau & $100 \%$ \\
3. & Kulit Kambing & $100 \%$ \\
4. & Kulit Babi & $100 \%$ \\
\hline & Primer universal yang digunakan dari
\end{tabular}
gen cytochrome $b$ sesuai publikasi Kocher et al. (1989), dengan susunan basa sebagai berikut :

Forward: L14841 (5'-CCA TCC AAC ATC TCA GCA TGA TGAAA-3')

Reverse: H15194 (5'-GCC CCT CAG AAT GAT ATT TGT CCT CA-3') 
dan menggunakan enzim restriksi BamHI dan BseDI untuk memotong DNA dari gen cytochrome $b$.

Metode ekstraksi dan purifikasi DNA menggunakan prosedur Sambrook et al. (1989), yang telah dimodifikasi, yaitu sampel $\pm 30 \mathrm{mg}$ sampel dipotong dan digerus dengan mortar hingga halus dan kemudian dimasukkan ke dalam tube kapasitas 1,5 ml. Ekstraksi diawali dengan menambahkan $500 \mu 1$ buffer TEN/STE setelah itu divortex, dan $30 \mu$ proteinase $K, 50$ $\mu 110 \%$ SDS, dan inkubasi kedalam water bath pada temperatur $42^{\circ} \mathrm{C}$ selama $18-19$ jam. Sebanyak $50 \mu \mathrm{l} 5 \mathrm{M} \mathrm{NaCl}, 400 \mu \mathrm{l}$ phenol, 400 $\mu 1$ CIAA dan inkubasi kedalam water bath dengan suhu $37^{\circ} \mathrm{C}$ selama $1 \mathrm{jam}$. Kemudian sentrifugasi $3.000 \mathrm{rpm}$ dengan suhu $4{ }^{\circ} \mathrm{C}$ selama 5 menit. Pindahkan supernatan ke tabung baru dengan menambahkan $50 \mu 15 \mathrm{M} \mathrm{NaCl}$ dan 800 $\mu 1$ ethanol absolut, kocok dengan tangan sampai terbentuk benang - benang putih. Inkubasi di freezer selama 1 jam dengan suhu $-20^{\circ} \mathrm{C}$. Sentrifugasi $8000 \mathrm{rpm}$ selama 5 menit, kemudian buang cairannya. Tambahkan 1000 $\mu 1$ ethanol $70 \%$. Kemudian sentrifugasi lagi $8000 \mathrm{rpm}$ dengan suhu $4^{\circ} \mathrm{C}$ selama 5 menit. Buang larutan dan tiriskan hingga tak ada larutan tertinggal selanjutkan keringkan menggunakan densikator selama \pm 19 jam sampai benar-benar kering dan yang terakhir menambahkan $50 \quad \mu \mathrm{l}$ TE dan simpan di temperatur $-20^{\circ} \mathrm{C}$ sampai digunakan.

Ekstraksi dan Purifikasi DNA mengikuti prosedur Wasko et al. (2003) yang telah dimodifikasi. Sebanyak $\pm 30 \mathrm{mg}$ sampel dipotong - potong, dimasukkan ke dalam tabung eppendorf 1,5 $\mathrm{ml}$. PBS dengan perbandingan 1:1 dan larutan buffer TNES sebanyak $400 \mu \mathrm{l}$ ditambahkan dalam tabung, kemudian divortex. $5 \mu 1$ RNAase ditambahkan dalam larutan. Larutan diinkubasi menggunakan waterbath pada suhu $42^{\circ} \mathrm{C}$ selama 1 jam. Larutan ditambah $6 \mu$ l proteinase $K$, kemudian diinkubasi lagi pada suhu $42^{\circ} \mathrm{C}$ semalaman untuk melisiskan jaringan. Larutan ditambahkan fenol, kloroform, dan isoamil alkohol (PCI) dengan perbandingan 25:24:1, kemudian divortex dan diinkubasi pada suhu ruang selama 5 menit dan diulangi hingga 3 kali, kemudian disentrifugasi $10.000 \mathrm{rpm}$ pada suhu $15^{\circ} \mathrm{C}$ selama 15 menit. Supernatan diambil dan dipindah ke tabung baru, kemudian ditambah $1 \mathrm{M} \mathrm{NaCl}$ dan etanol absolut, vortex, dan diinkubasi pada suhu ruang selama 5 menit. Sentrifugasi $10.000 \mathrm{rpm}$ pada suhu $15^{\circ} \mathrm{C}$ selama 15 menit. Supernatan yang terbentuk dibuang, pellet diambil kemudian dicuci dengan $100 \mu 1$ etanol 70\%, kemudian disentrifugasi 10.000 rpm pada suhu $5^{\circ} \mathrm{C}$ selama lima menit. Pencucian dilakukan sebanyak $2-3$ kali. Supernatan yang terbentuk dibuang, kemudian pellet dikeringkan. $30 \quad \mu l \quad$ TE buffer ditambahkan dalam tabung eppendorf, kemudian disimpan pada suhu $-20^{\circ} \mathrm{C}$.

Amplifikasi gen $c y t b$ dilakukan dalam volume akhir $25 \mu$ l yang mengandung $\mathrm{dH}_{2} \mathrm{O} 2$ $\mu 1$, Green PCR master mix $20 \mu \mathrm{l}(2 \mathrm{X}$ hot start PCR buffer, $400 \mu \mathrm{M}$ dATP, $400 \mu \mathrm{M}$ dGTP, 400 $\mu \mathrm{M}$ dCTP, $400 \mu \mathrm{M}$ dTTP, dan $4 \mathrm{mM} \mathrm{Mg}^{2+}$ ) (Thermo Scientific), primer universal reverse 1 $\mu 1 \quad(20$ pmol $)$ (Thermo Scientific), primer universal forward $1 \mu \mathrm{l}(20 \mathrm{pmol})$ (Thermo Scientific) dan DNA hasil ekstraksi $1 \mu$ l. Amplifikasi dilakukan dengan program sebagai 
berikut: predenaturasi $94^{\circ} \mathrm{C}$ selama 2 menit, denaturasi $95^{\circ} \mathrm{C}$ selama 36 detik, annealing $53^{\circ} \mathrm{C}$ selama 72 detik, extension $72^{\circ} \mathrm{C}$ selama 84 detik, dengan siklus PCR diulang sebanyak 35 kali. Post extension $72^{\circ} \mathrm{C}$ selama 3 menit, kemudian suhu diturunkan sampai mencapai $30^{\circ} \mathrm{C}$. kemudian diambil $8 \mu \mathrm{l}$ masing - masing sampel dari hasil PCR ditambahkan loading dye $2 \mu \mathrm{l}$ di elektroforesis pada $100 \mathrm{~V}$ gel agarose 2 $\%$ selama 30 menit dalam buffer TBE $1 X$. Marker 100 bp (Thermo Scientific) digunakan sebagai DNA ladder. Hasil PCR disimpan pada suhu $-20^{\circ} \mathrm{C}$ sampai digunakan untuk analisis selanjutnya.

Elektroforesis. Pengecekan kualitas DNA pada isolasi DNA dengan elektroforesis diambil $12 \mu \mathrm{l}$ masing - masing sampel dari isolasi DNA ditambahkan $3 \mu$ l loading dye dimasukkan kedalam gel agarose $1 \%$ ditambahkan ethidium bromida sebanyak $5 \mu \mathrm{l}$, tegangan 100 volt selama 30 menit dalam buffer TBE 1X. Pada amplifikasi PCR gen cytochrome $b$ dengan elektroforesis diambil $10 \mu 1$ masing masing sampel dari hasil PCR ditambahkan $3 \mu 1$ loading dye dimasukkan kedalam gel agarose $2 \%$ ditambahkan ethidium bromida sebanyak 5 $\mu 1$, tegangan 100 volt selama 30 menit dalam buffer TBE 1X. Marker 100 bp (Thermo Scientific) digunakan sebagai DNA ladder.

\section{HASIL DAN PEMBAHASAN}

\section{Isolasi DNA}

Pada penelitian memungkinkan menghasilkan isolat DNA yang berbeda pada metode isolasi yang digunakan. Hal ini tergantung pada efektifitas metode tersebut dalam menghasilkan isolat DNA baik dari segi kualitas maupun kuantitas serta efisiensi waktu isolasinya. Metode isolasi sangat bervariasi baik dalam pelaksanaannya dalam mendapatkan data, tata cara, maupun tingkatan target data yang diinginkan sesuai pelaksanaannya, sumberdaya manusia, fasilitas, dan dana penelitian (Ardiana, 2009).

Metode Wasko et al. (2003), dan metode Sambrook et al. (1989), yang dimodifikasi merupakan metode isolasi untuk jaringan hewan. Metode Sambrook dinilai lebih tepat diaplikasikan pada jaringan hewan karena mampu menghasilkan kualitas DNA yang lebih baik dibandingkan dengan metode Wasko (Gambar 1).

Berdasarkan hasil penelitian isolasi DNA didapatkan hasil bahwa dengan metode sambrook yang telah dimodifikasi didapatkan hasil yang lebih baik dibandingkan dengan metode Wasko. Terlihat adanya pita - pita DNA yang terlihat jelas dan terang pada keempat sampel kulit dibandingkan dengan metode Wasko, namun pada keempat sampel kulit nampak adanya smear. Adanya smear menandakan adanya kontaminasi RNA, DNAnya mengalami degradasi saat isolasi dimana fragmen - fragmen DNA dengan ukuran yang berbeda tertahan oleh gel sesuai dengan ukurannya (Vivikanada, 2014). Metode sambrook memiliki hasil isolasi DNA yang lebih baik dibandingkan dengan metode Wasko. Hal ini disebabkan karena adanya perbedaan langkah - langkah dalam tahap isolasi DNA seperti pada penggunaan reagen tertentu dengan volume yang lebih besar dan perbedaan konsentrasi yang digunakan (Fitrianingsih, 2013). 

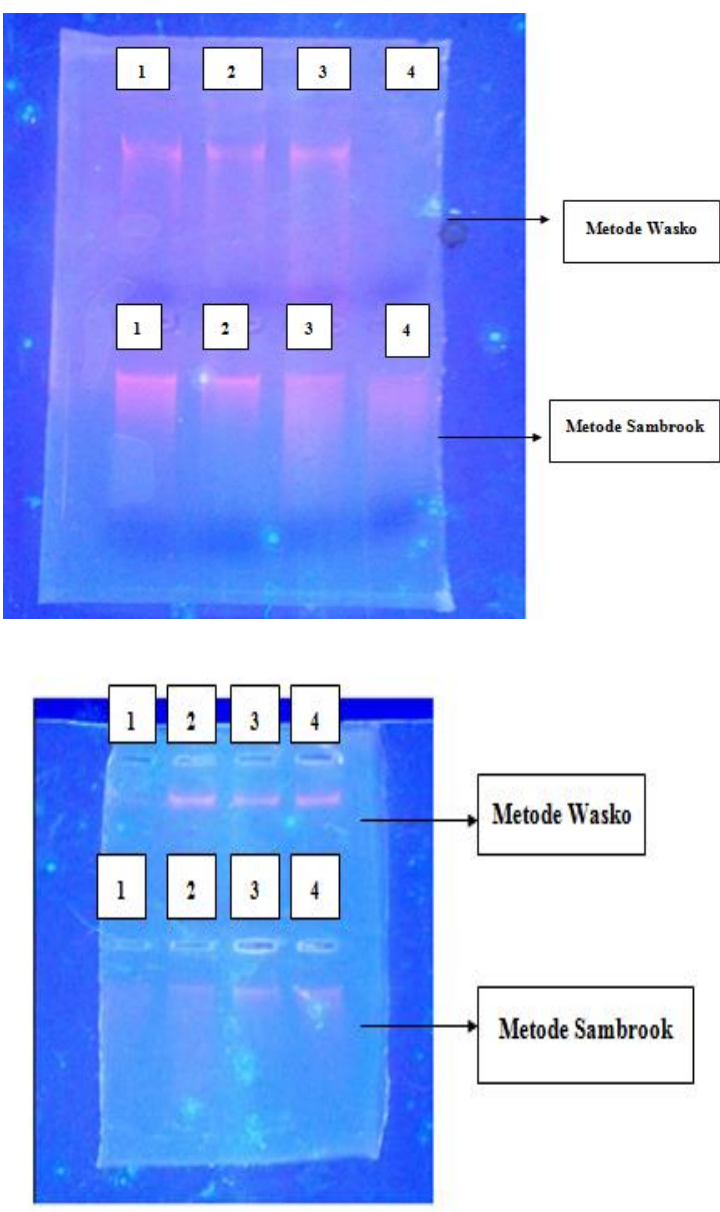

Gambar 1. Elektroforesis Hasil Isolasi DNA. Metode Wasko pada bagian atas: Lajur $1=$ Sampel kulit sapi, Lajur 2 = Sampel kulit kerbau, Lajur 3 = Sampel kulit kambing, dan Lajur 4= sampel kulit babi. Metode Sambrook pada bagian bawah : Lajur 1 = Sampel kulit sapi, Lajur 2 = Sampel kulit kerbau, Lajur 3 = Sampel kulit kambing, dan Lajur 4= sampel kulit babi.

\section{Kosentrasi dan Kemurnian Metode Isolasi DNA}

Nilai absorbansi 260 pada spektrometer merupakan angka penyerapan maksimal oleh nukleotida, sedangkan absorbansi $280 \mathrm{~nm}$ adalah penyerapan maksimal protein. konsentrasi DNA didapatkan dengan mengalihkan nilai absorbansi $260 \mathrm{~nm}$ x 50 x faktor pengenceran (Sulandari dan Zein, 2003). Nilai kuantitas DNA genom dapat dilihat pada Tabel 2.

Tabel 2. Nilai Kuantitas DNA Genom

\begin{tabular}{llllll}
\hline \hline \multirow{2}{*}{ Metode } & Sampel & \multicolumn{2}{c}{ Panjang Gelombang } & \multicolumn{2}{l}{ Konsentrasi } \\
\cline { 3 - 4 } & & $\lambda 260(\mathrm{~nm})$ & $\lambda 280(\mathrm{~nm})$ & $\begin{array}{l}\text { Rasio } \\
\text { DNA template } \\
(\mu \mathrm{g} / \mathrm{ml})\end{array}$ & $\begin{array}{l}\text { kemurnian } \\
\text { DNA }\end{array}$ \\
\hline \multirow{3}{*}{ Wasko } & Kulit sapi & 0,147 & 0,168 & 367,5 & 0,875 \\
& Kulit kerbau & 0,135 & 0,153 & 337,5 & 0,882 \\
& Kulit kambing & 0,155 & 0,169 & 387,5 & 0,917 \\
& Kulit babi & 0,159 & 0,165 & 397,5 & 0,964 \\
Sambrook & Kulit sapi & 0,152 & 0,175 & 380 & 0,868 \\
& Kulit kerbau & 0,141 & 0,161 & 352,5 & 0,876 \\
& Kulit kambing & 0,158 & 0,178 & 395 & 0,887 \\
& Kulit babi & 0,169 & 0,172 & 422,5 & 0,983 \\
\hline
\end{tabular}

Berdasarkan nilai kuantitas isolasi DNA genom didapat nilai kemurnian antara 0,8 $-0,9$, hal ini menunjukkan bahwa DNA sampel tersebut telah terkontaminasi oleh protein atau phenol didalam larutan (Brown, 2010). Menurut Sambrook et al. (1989), hasil isolasi DNA dikatakan murni apabila memiliki nilai kemurnian antara 1,8 hingga 2,0. Secara kuantitas metode Sambrook memiliki lebih baik daripada metode Wasko. Perbedaan tingkat konsentrasi DNA mengakibatkan perbedaan ketebalan pita. Hal ini karena perlakuan fisik yang berbeda dan kemampuan buffer ekstraksi dalam memecah sel. Fungsi buffer ekstraksi untuk mempermudah dalam memecahkan sel dan menentukan konsentrasi DNA yang 
dihasilkan. kesimpulannya bahwa metode isolasi memiliki pengaruh besar terhadap kualitas dan kuantitas DNA hasil isolasi.

\section{Amplifikasi PCR Gen Cytochrome b}

Pada penelitian ini amplifikasi template DNA menggunakan pasangan primer universal L14841 (5'- CCA TCC AAC ATC TCA GCA TGA GCA TGA TGA AA - 3') sebagai forward dan H15194 (5'-GCC CCT CAG AAT GAT ATT TGT CCT CA-3') sebagai reverse primer. Pasangan primer ini menghasilkan amplikon sebesar 359 bp. Hasil amplifikasi DNA sampel kulit sapi, kerbau, kambing, dan babi dengan menggunakan metode Wasko dan metode Sambrook dapat dilihat pada Gambar 2 dan 3.

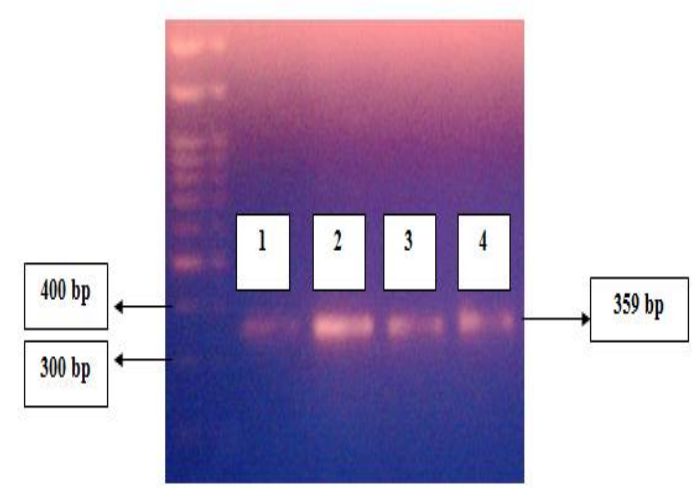

Gambar 2. Elektroforesis Produk PCR. Metode Wasko :Lajur 1 = Sampel kulit sapi, Lajur 2 = Sampel kulit kerbau, Lajur 3 = Sampel kulit kambing, dan Lajur 4= sampel kulit babi.

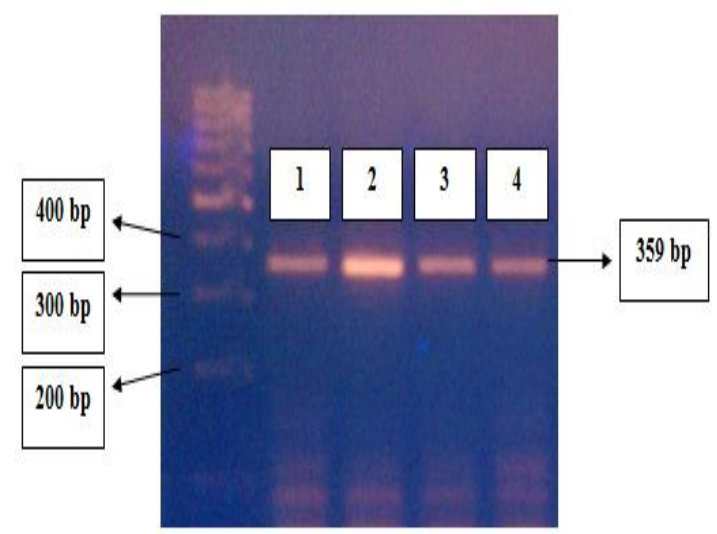

Gambar 3. Elektroforesis Produk PCR Metode Sambrook: Lajur 1 = Sampel kulit sapi, Lajur 2 = Sampel kulit kerbau, Lajur 3 = Sampel kulit kambing, dan Lajur 4= sampel kulit babi.

Berdasarkan hasil amplifikasi PCR gen $c y t \quad b$ DNA yang diperoleh dari metode Sambrook yang dimodifikasi dengan metode Wasko mampu mengamplifikasi sampel kulit sapi, kerbau, kambing, dan babi. Amplifikasi gen cyt b pada sampel kulit menghasilkan ukuran fragment 359 bp. Hal sesuai dengan penelitian Erwanto et al. (2011), menghasilkan ukuran fragmen 359 bp pada sampel daging babi dan daging ayam. Terlihatnya pita DNA yang sejajar menunjukkan bahwa keberadaan sampel kulit telah diisolasi pada metode Sambrook maupun Wasko dan dapat terdeteksi sehingga menunjukkan bahwa metode isolasi DNA dapat digunakan.

\section{KESIMPULAN DAN SARAN}

Isolasi DNA pada kulit sapi, kerbau, kambing, dan babi dengan menggunakan metode Sambrook yang dimodifikasi menghasilkan kualitas dan kuantitas DNA yang lebih baik dibandingkan dengan metode Wasko. Hasil amplifikasi DNA gen cyt b menghasilkan ukuran fragmen sebesar 359 bp.

\section{DAFTAR PUSTAKA}

Ardiana, D.W. (2009). Teknik isolasi DNA genom tanaman pepaya dan jeruk dengan menggunakan modifikasi bufer CTAB. Buletein Teknik Pertanian, 14, $12-16$.

Brown, T.A. (2010). Gene Cloning and DNA Analysis. Sixth Edition. Faculty of Life Science. University of Manchester. 
Erwanto, Y., M.Z. Abidin, A. Rohman, \& Sismindari. (2011). PCR - RFLP Using BseDI enzyme for pork authentication in sausage and nugget products. Media Peternakan, $14-18$.

Fitrianingsih. 2013. Optimalisasi Isolasi DNA pada Daging Olahan sebagai Dasar untuk Deteksi Kontaminasi Daging Babi. (Tesis). Program Pascasarjana Fakultas Peternakan. Universitas Gadjah Mada.

Kocher, Z.,A. S.V. Thomas, S. Meyer, Edwards \& F.X. Paabo. (1989). Dynamic of mitochondrial DNA evolution in animal: amplifications and secuencing with conversed primers. Proceedings of the National Academy of science of the USA, 86, 6169-6200.

Sambrook, J., E.F. Fritch and T. Maniatis. (1989). Molecular Cloning, A. Laboratory Manual. $2^{\text {nd }}$. Cold Spring Harbour Lab. Press. New York.

Sulandri, S. \& M.S.A. Zein (2003). Panduan Praktikum Laboratorium DNA. Bidang Zoologi. Pusat Penelitian Biologi. Lembaga Ilmu Pengetahuan Indonesia.

Vivikananda, E. (2014). Deteksi DNA Babi dan DNA Sapi dengan Menggunakan Metode Insulated Isothermal Polymerase Chain Reaction (PCR). (Skripsi). Program Sarjana Fakultas Farmasi. UIN Syarif Hidayatullah Jakarta.

Wasko, A.P., C. Martins, C. Oliveira, \& F. Foresti. (2003). Non-destructive genetic sampling of fish. An improved method for DNA extraction from fish fins and scale. Hereditas, 138, $161-$ 165 . 